\title{
THE IMPACT OF PERCEIVED ORGANIZATIONAL SUPPORT ON ORGANIZATIONAL DEPRESSION AND ORGANIZATIONAL DEDICATION
}

\author{
ÖRGÜTSEL DESTEK ALGISININ ÖRGÜT DEPRESYONU VE \\ ADANMIŞLIK ÜZERİNDEKİ ETKİSİ
}

\author{
Gülbeniz AKDUMAN* ${ }^{*}$ \\ Zeynep HATIPOĞLU ${ }^{* *}$ iD
}

\begin{abstract}
Psychological status of employees and feelings of belonging to the organization have gained considerable momentum within organizations. In this study the impact of perceived organizational support on organizational depression and dedication is examined. To do that a questionnaire form consisting of four parts was applied to 237 participants that were reached by convenience sampling method. All the filled questionnaire was included in the analysis. The demographic information form is in the first part, "Organizational Depression Scale" developed by Sezer (2011) is in the second part, "Perceived Organizational Support Scale-Short Form" developed by Eisenberger et al (1992) and adapted to Turkish by Öztürk and Eryeşil (2016) is in the third part, "Job Engagement Scale" developed by Rich et al (2010) and adapted to Turkish by Kurtpinar (2011) is in the fourth part of the questionnaire form. Confirmatory factor analysis method within the scope of validity of the scales, item analysis (inter-item correlations, Cronbach Alpha) method within the scope of the reliability were used. Based on the result, the perception of organizational support has a negative and significant effect on organizational depression, and a positive and significant effect on organizational dedication. Perception of organizational support, organizational depression and organizational dedication levels do not significantly differ by gender, marital status and generations.
\end{abstract}

Keywords: Perceived organizational support, organizational depression, organizational dedication JEL Classification: L00, L20, L29

* Dr., Bilgi University, Institute of Graduate Programs, Human Resources Management Program; gulbeniz@akduman.com

** Assoc. Prof. Dr., İstanbul Arel University, Faculty of Economics and Administrative Sciences, Department of Business Administration, zynhatipoglu@gmail.com

To cite this article: Akduman, G. \& Hatipoglu, Z. (2020). The impact of perceived organizational support on organizational depression and organizational dedication. Journal of Research in Business, 5(1), 96-126.

"Çalışmada Etik Kurul izni gerekmemektedir." 
Öz

Çalışanların psikolojik durumları ve örgüte ait olma duyguları örgütler için önemli bir ivme kazanmıştır. Örgütsel destek algısının örgüt depresyonu ve adanmışlık üzerindeki etkisinin incelendiği bu çalışmada, kolayda örnekleme yöntemi ile ulaşılan 237 katılımcıya dört bölümden oluşan bir anket formu online olarak uygulanmıştır. Doldurulan tüm anketler analizlere dahil edilmiştir. Anket formunun birinci bölümünde demografik bilgi formu, ikinci bölümünde Sezer (2011) tarafından geliştirilen Örgüt Depresyonu Ölçeği, üçüncü bölümünde Eisenberger ve arkadaşları (1992) tarafından geliştirilen ve Öztürk ve Eryeşil (2016) tarafından Türkçe’ye uyarlanan Algılanan Örgütsel Destek Ölçeği - Kısa Formu, dördüncü bölümünde Rich ve arkadaşları (2010) tarafından geliştirilen ve Kurtpınar (2011) tarafından Türkçe’ye uyarlanan Örgütsel Adanmışlık Ölçeği yer almaktadır. Ölçeklerin geçerlik çalışmaları kapsamında doğrulayıcı faktör analizi; güvenirlik çalışması kapsamında madde analizi (madde toplam korelasyonu ve Cronbach Alpha) yöntemleri kullanılmıştır. Araştırma sonucuna göre, örgütsel destek algısının örgüt depresyonu üzerinde negatif yönlü ve anlamlı etkisi, örgütsel adanmışlı üzerinde ise pozitif yönlü ve anlamlı etkisi vardır. Örgütsel destek algısı, örgüt depresyonu ve örgütsel adanmışlık cinsiyete, medeni duruma ve kuşaklara göre anlamlı farklılık göstermemektedir.

Anahtar Kelimeler: Örgütsel destek algısı, örgüt depresyonu, adanmışlık

JEL Sınıflaması: L00, L20, L29

\section{Introduction}

It has become much more difficult to survive in a rapidly changing world for organizations. Especially, recent researches on digital transformation, automation and artificial intelligence is shown that it will require a faster conversion in organizational structures, competencies expected from employees and in business processes. Organizational dedication of employees is only \%17 in Turkey according to "The Future of Our Business: Turkey's Talent Transformation in the Digital Age" research report conducted by McKinsey in Turkey (Huchzermeier et al., 2019). Factors such as salary and benefits are not sufficient for employees to continue working in a business. Today's employees want spiritual support as well as financial opportunities.

In line with the increasing demands of the new generations, positive organizational behavior variables (hope, optimism, resilience and self-efficacy), which have become increasingly important after 2000, have become important for business (Çalışkan, 2014: 363). Within the framework of the research model, the concepts of "organizational depression", which is a negative employee behavior that may be associated with positive organizational behavior variables, and the "organizational dedication and perceived organizational support " concepts, which are accepted as part of the positive organizational behavior trend, were selected as variables to be examined.

Considering all these developments, attract and retain qualified manpower for organizations is much more difficult. In addition, due to rapid changes at the organizational level, the support of organizational effort to empower the employees and adding meaning to job have become more important. There is not a research that examines the impact of perceived organizational support on organizational depression and dedication. To help fill this need, the authors investigate the impact of the perceived organizational support on organizational depression and dedication in this research. In the research model were defined perceived organizational support is which as independent variable, and organizational depression and organizational dedication as dependent variables. 
The perception of organizational support will be discussed first, then the concepts of organizational depression and organizational commitment will be explained in this study. Then, the research and results will be explained by associating these three concepts with the theoretical background.

\section{Literature Review}

\subsection{Perceived Organizational Support}

Workplaces provide employees moral opportunities as well as financial opportunities. Employees want to know that they are supported by the organization they work for. Perceived organizational support is a concept that expresses the efforts of its employees are noticed by the organization. In this context, perceived organizational support ensures employee happiness and increases satisfaction.

Organizational support means that the organization cares about the well-being of its members, and to being interested with complaints, and attempt to help employees who have problems and treating them fairly (Akçakanat, Uzunbacak \& Köse, 2018). The perception of organizational support can be considered a psychological contract shaped by the belief that the organization gives value to the employee and the support it gives to its personal well-being (Chen et al., 2009). Researches show that perception of support is created by considering performance-reward relationship between managers and employees and this perception has many benefits (Eisenberger \&Stinglhamber, 2011). In particular, human resources practices, opinions about organizational justice and the structure of work effect to support perception (Stinglhamber, 2020). Similarly, appreciation of the employee is causing to develop positive feelings for work and more efforts are being made to achieve organizational goals. When evaluated within the scope of social change theory the behavior of employees is shaped according to the social relationships they are in (Blau, 1964).

Consequently, social relations of the employee have two determinants and perceived organizational support is one of these determinants. Another determinant is perceived manager support. In accordance with the reciprocity principle, support which is believed to come from the organization requires the employee to help the organization or at least avoiding harmful behavior (Düşükcan, Demirel \& Sezgin, 2019). The support provided by the organizations (such as work-private life balance) is perceived abstractly more than the support provided by the managers (such as mentoring, wage increase) (Probst et al., 2018). However, considered that managers are affected by the norms and culture of the organization, the support provided by the manager is also part of the perception of organizational support. According to Levinson (1965), the person's behavior is attributed to the organization, and employees give tangible appearance by personalizing organization. This is because; the organization's culture, norms and policies and responsibility of the employee are effective on the formation of the roles within the organization, maintenance and the power to be exhibited (Diken et al., 2019).

The value the organization gives to its employees may be a sign that they are accepted and requested within the organization. The fact that the organization meets the needs of the employees, caring 
about the contributions of the employees and caring for their interests may cause the employees to respond to the benefit of the organization (Demircan \&Y1ldız, 2009). Organizations wishing to increase the perceived organizational support are recommended to act on the following issues (Özdevecioğlu, 2003: 116):

- Consider the creative ideas, suggestions and criticisms of the employees and put these suggestions into practice,

- Provide occupational safety to the employees,

- Ensure that human relations within the organization are positive,

- Improving internal communication,

- Treat employees fairly and equally,

- Working for the happiness of the employees,

- Ensure the participation of employees in decisions.

Actions that increase perceived organizational support reduce employee depression and increase employee commitment (Akabas \& Kurzman, 2005: 217) and was found as a significant variable on impacting employee commitment (İnce, 2016).

\subsection{Organizational Depression}

Hippocrates is the person who made first the clinical description of depression, defined as melancholy in ancient times in the fourth century BC (Beck, 1975). Depression is an affective disorder with traces in Egyptian, Chinese and Greek inscriptions; lived in human history for more than 2000 years (Olshan, 1982). While it is normal emotion for every person to feel sadder and more troubled from time to time, when this negative emotion persists for a long time starts problems to communication, focus and decision making (McGraw-Hill, 2016). Changes in both emotion and behavior are observed of the person who is depressed. The emotional, cognitive, motivational and physical symptoms of depression are listed below (Smith et al., 2016):

- Emotional symptoms: sadness, anhedonia,

- Motivational symptoms: Passivity, not being inclined to start or continue activities,

- Cognitive symptoms: Negative thoughts about self, despair, low concentration, poor memory, confusion,

- Physical symptoms: Appetite and sleep patterns changes, fatigue, increased pain and aches.

Depression is a disease reduces to person's joy of living; causing introverted and that reduces the pleasure it receives from life. The person who is depressed does not enjoy from life and does not want to live and they tend to commit suicide (Yüksel, 2006). Depression is a psychiatric disorder and it is a public health problem with common of $20 \%$ among adults (Güleç, 2014). Nine symptoms have been defined as the criteria for depression (DSM-V) for a person to be diagnosed with depression. Person must experience at least five of these nine situations. These situations are; to be in emotional distress 
for most of the 24 hours, excessive weight gain or loss, excessive or inadequate sleep, approaching to events with excessive agitation or unresponsiveness, feeling weak and tired, self-blame and feel insignificant, difficulty focusing, not seeing life as valuable, proximity to suicide. (Köroğlu, 2014).

Depression that is specific to human, it can be seen in organizations with cultural and structural features such as people (Gray, 2008). Joy of life itself shows in organizations, as reluctance, unhappiness, not being enthusiastic, doing business or attempting. Employees loses joy of life when depressed (Dökmen, 2004). Employees with depression lose their will to work and they do not plan or work for the future in organizations. In a sense that it can be said that they have lost their vision (Toytok \& Uçar, 2018).

Despair is the most important indicator of depression within the organization (Sezer, 2010). There are several symptoms that show depression in addition to despair within organization (Bell DeTienne et al., 2020):

- No effort to reach a common vision,

- Closedness and reluctance to change,

- Inefficiency,

- Boredom and unwillingness between the employees,

- Difficulties and delays when decision making,

- Discomfort, increased absenteeism, leaving from job,

- Communication problems between units when need,

- Not striving for performance and success and not being willing.

Stress, burnout, organizational culture and organizational alienation constitute are the organizational factors. Communication and management styles of managers, psychological violence, communication and conflict between employees are the managerial factors and personality traits, individuals' culture and prejudices constitute are the personal factors (Aktürk, 2019).

Organizational depression negatively affects efficiency and effectiveness in the organization's activities and even can be cause it to disappear (Gray, 2008). There are many studies indicates the negative effects of organizational depression on organizational performance and efficiency (Cohen \& Cohen, 1993; Bilchik, 2000; Dökmen, 2014). Organizational depression varies depending many factors such as socio-demographic characteristics, organization's practices, and managers. It has been reported in researches on depression that women are twice prone to depression than men as likely due to both their biological structure and negative emotions (Gerrig, Zimbardo, 2015). While person's depression varies according to the sex, organizational depression does not differ with respect to gender and marital status (Bakan et al., 2014, Çeler, 2015; Keleş, 2016; Turhan, 2019; Uçar, 2016). As people grow older, their resilience increases with their experience in business life, but their depression decreases in parallel with the stress they experience (Bakan vd., 312). 


\subsection{Organizational Dedication}

Organizational dedication is defined as the employees have a strong belief in the aims, and values of the organization and willingness for intensive efforts exerted to achieve these objectives (Boylu, Pelit \& Güçer, 2007, Taştan, 2014). Dedication represents a strong commitment to working and covers the sense of materiality, enthusiasm, inspiration, pride and struggle cases. Employees who are dedicated thinks that; their job is interesting, that requires struggle, that serve a purpose and that significant; their job gives them inspiration; therefore, they work eagerly, and they are proud from their job. In this case dedication is the focus of the employee on his job and that he was happily caught up in the workflow (Çalışkan, 2014). Dedication is about the employee's commitment to job, and closely to the mutual expectations between the employee and the organization (Gill \& Mathur, 2007).

Dedication is shaped in accordance with the individual's perception of self-image and paying attention to performance (Firal et al. 2017). Dedication (can also be described as conscientious initiative and organizational citizenship) means to act with great desire to successfully complete an own task or voluntarily performing tasks that are not part of the job, and demand challenging tasks. Dedication contains interpersonal support, collaboration, and helping improve co-worker's performance. It ensures the protection of interpersonal and social context for the effective performance of duties (Harzer \& Ruch, 2014).

Dedication has three dimensions: cognitive, physical and emotional (Yavan, 2016). Emotional dedication is expression of some psychological conditions (meaningfulness, trust etc.). Cognitive dedication is that the employee always ready for job, show vitality, and aware what expected from him. Physical dedication is an indication of the physical involvement to the job (Aytekin, 2016).

Important studies have been carried out to determine the factors that increase the level of organizational dedication, which has particularly important consequences for both the individual and the organization. The sense of having a meaningful job depends on the high harmony between the work and the employee and finding themselves valuable and important while doing their work (Kahn, 1990). It has been stated that personnel empowerment and similar practices indirectly increase the dedication of the employees to the job (Laschinger vd., 2009).

Organizational dedication positively affects organizational performance (Sonnentag, 2003). Organizational dedication supports the employees to use their capacity at the highest level, while having a positive effect on the performance of the company (Manfred \& De Vries, 2001: 40). Also, organizational dedication mediates the relationship between leader-member exchange and organizational citizenship behaviors (Muldoon et al, 2017).

Psychological status of employees and feelings of belonging to the organization have gained considerable momentum within organizations. Organizational depression is one of the psychological negative situations of employees that have been on the agenda in recent years. Organizational depression has the opposite effect of organizational dedication. Organizational 
depression negatively affects efficiency and effectiveness in the organization's activities and even can be cause it to disappear (Gray, 2008). There are many studies indicates the negative effects of organizational depression on organizational performance and efficiency (Cohen \& Cohen, 1993; Bilchik, 2000; Dökmen, 2014).

Findings from the research conducted by Ince (2016) showed that organizational support is an effective factor on organizational dedication. According to this result, as employees' perception of organizational support increases, their level of organizational dedication also increases. In the light of these results, the fact that the companies take into consideration the following points can provide important gains for them. If employees are asked to take initiative, be satisfied with their work, feel loyalty to the organization and have low intention to quit, their organizational dedication should be increased. In short, it is possible to use its physical and mental energy for the benefit of the organization by dedicating itself to the work. However, the employee who is committed to his job can be expected to perform at a high level. At this point, increasing the perception of organizational support of employees is an important factor in increasing their organizational dedication.

Perceived organizational support, dedication and organizational depression are variables that affect organizational performance. It is considered that there is a positive relationship between the three of the organizational dedication and organizational depression considering the characteristics of the perceived organizational support perception. The following hypotheses have been developed with a perspective matured by these thoughts. The purpose of this research is to analyze the impact of perceived organizational support on organizational depression and dedication.

In the research model were defined perceived organizational support is which as independent variable, and organizational depression and organizational dedication as dependent variables (Figure 1).

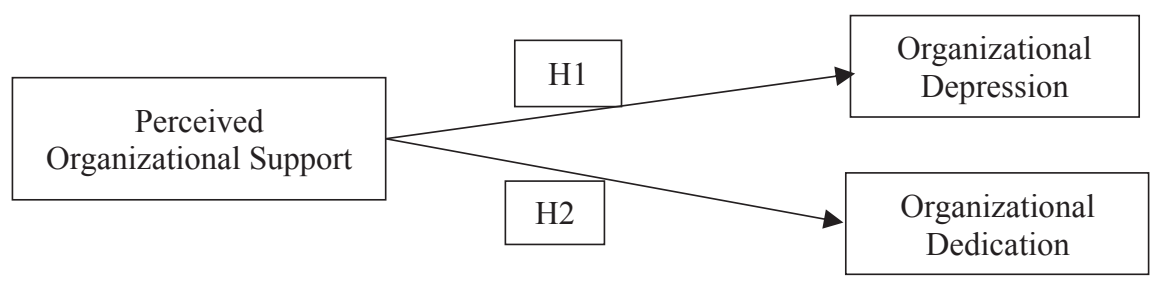

Figure 1: Research Model

The hypotheses of the research are as follows:

H1: The perceived organizational support has a negative and significant effect on organizational depression.

H2: The perceived organizational support has a positive and significant effect on organizational dedication. 


\section{Research Methodology, Analyses and Results}

\subsection{Sampling and Data Collection}

A questionnaire form was applied to 237 participants from different sectors that were reached by convenience sampling method within 3 months. All the filled questionnaire was included in the analysis.

A questionnaire form consistsing of four parts was used in the study. Demographic information form is located on the first section of the questionnaire consisting participants' gender, age, marital status, education level, working period in the business, position in the business, working period in the position, total working period and number of employees in the business.

Organizational Depression Scale developed by Sezer (2011) is located on the second section of the questionnaire form. The scale consists of a five-point Likert type (1: strongly disagree, 5: strongly agree) 42 items and a dimension. The high score it means the high level of organizational depression of the employees after reversed were 24 items $(1,2,6,7,8,9,11,14,15,19,20,21,23,25,26,27,29$, $31,33,34,35,37,40,42$ ) with positive expressions.

In the third part of the questionnaire form located, Perceived Organizational Support Scale - Short Form - developed by Eisenberger et al. (1992) and adapted to Turkish by Öztürk and Eryeşil (2016). The scale consists of a five-point Likert type (1: strongly disagree, 5: strongly agree) 10 items and a dimension. The high score it means perceived organizational support is high by the employees.

In the fourth part of the questionnaire form located, Job Engagement Scale (referred to as Organizational Dedication in this study) developed by Rich et al. (2010) and adapted to Turkish by Kurtpinar (2011). The scale consists of a five-point Likert type (1: strongly disagree, 5: strongly agree) 18 items and three dimensions (cognitive, physical, emotional dedication) consisting of 6 items each. The high score it means perceived organizational support is high by the employees. The high scores on the scale it means, employee behavior towards organizational dedication is the high level.

\subsubsection{Validity and Reliability Analysis Results of the Organizational Depression Scale}

In the first phase of the CFA performed in accordance with the original structure of the organizational depression scale (42 items and one dimension), it was determined that the factor loads of all items were not within the appropriate ranges and the model fit indices were not at the appropriate levels. Therefore, the items with low factor load affecting the model fit were removed from the scale starting from the lowest factor load and on the basis of modification indices and theoretical relevance, seventeen covariance were added (i1-i2, i31-i35, i16-i18, i7-i8, i19-i23, i18-i21, i13-i28, i11-i19, i31-i33, i20-i31, i16-i26, i14-i42, i16-i28, i14-i37, i11-i37, i9-i33, i6-i23), and the results in Table 1 were obtained. According to the results in Table 1, and Figure 2 the model fit indices generally reached a very good level and it was determined that factor loads were in appropriate ranges after removing from the scale 15 items with inappropriate factor load, and covariance connections suitable to modification suggestions. 
Table 1: Model Fit Indices of Organizational Depression

\begin{tabular}{ccc}
\hline Indices & CFA & CFA $^{*}$ \\
& 42 items and a dimension & 27 items and a dimension \\
\hline $\mathrm{X}^{2} / \mathrm{df}$ & 2.728 & 1.941 \\
RMSEA & .086 & .063 \\
SRMR & .076 & .046 \\
GFI & .634 & .850 \\
NNFI & .737 & .924 \\
CFI & .750 & .933 \\
Factor Load (min/max) & $.15 / .82$ & $.50 / .83$ \\
\hline
\end{tabular}

${ }^{\star}$ With covariance connections

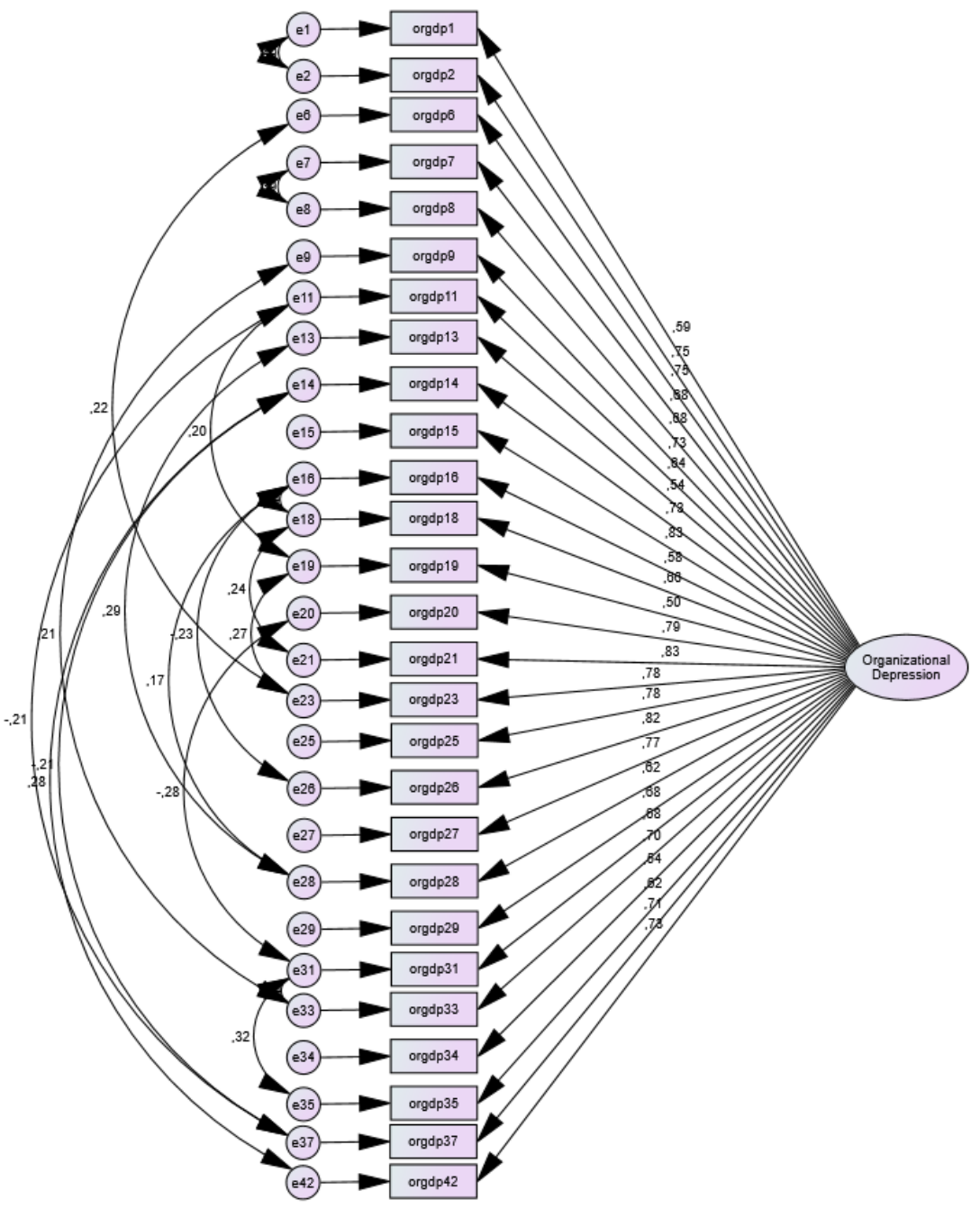

Figure 2: CFA Diagram of Organizational Depression Scale

CFA and item analysis results are shown in Table 2. According to the validity and reliability analysis results in Table 2, it been identified factor loadings of all items were appropriate range in the 
organizational depression scale, and t values are significant at the level of 0.01 . The Cronbach Alpha coefficient of the scale was determined as .96 , and the item-total correlation was found to be higher than .30 (between.54 and .80) for all items in the scale. According to validity and reliability analysis, it was determined that the scale of organization depression is a reliable and valid scale with its 27 items and one-dimensional structure.

Table 2: CFA and Item Analysis Results of Organizational Depression Scale

\begin{tabular}{|c|c|c|c|c|c|c|c|}
\hline Item No & Std. $\beta$ & $\mathrm{t}$ & $\mathrm{r}$ & Item No & Std. $\beta$ & $\mathrm{t}$ & $\mathrm{r}$ \\
\hline 1 & .59 & & .61 & 21 & .83 & $9.90^{\star *}$ & .80 \\
\hline 2 & .75 & $12.53^{* *}$ & .75 & 23 & .78 & $9.48^{* *}$ & .76 \\
\hline 6 & .75 & $9.26^{* *}$ & .73 & 25 & .78 & $9.55^{\star *}$ & .76 \\
\hline 7 & .68 & $8.67^{\star *}$ & .69 & 26 & .82 & $9.80^{* *}$ & .77 \\
\hline 8 & .68 & $8.64^{\star *}$ & .70 & 27 & .77 & $9.43^{\star *}$ & .75 \\
\hline 9 & .73 & $9.13^{* *}$ & .71 & 28 & .62 & $8.11^{* *}$ & .63 \\
\hline 11 & .64 & $8.24^{\star *}$ & .63 & 29 & .68 & $8.65^{\star *}$ & .66 \\
\hline 13 & .54 & $7.33^{* *}$ & .56 & 31 & .68 & $8.69^{* *}$ & .67 \\
\hline 14 & .73 & $9.12^{* *}$ & .71 & 33 & .70 & $8.86^{* *}$ & .70 \\
\hline 15 & .83 & $9.91^{* *}$ & .80 & 34 & .54 & $7.33^{\star *}$ & .54 \\
\hline 16 & .58 & $7.66^{* *}$ & .58 & 35 & .62 & $8.09^{* *}$ & .61 \\
\hline 18 & .66 & $8.47^{\star *}$ & .67 & 37 & .71 & $8.91^{\star *}$ & .67 \\
\hline 19 & .50 & $6.86^{* *}$ & .50 & 42 & .73 & $9.09^{* *}$ & .73 \\
\hline 20 & .79 & $9.57^{\star *}$ & .76 & & & & \\
\hline \multicolumn{8}{|c|}{$\alpha=.96$} \\
\hline
\end{tabular}

\subsubsection{Validity and Reliability Analysis Results of the Perceived Organizational Support Scale}

In the first phase of the CFA performed in accordance with the original structure of the perceived organizational support scale (10 items and one dimension), it was determined that the factor loads of all items were within the appropriate ranges. But the model fit indices were not at the appropriate levels. Therefore, covariance connections were made primarily, on the basis of modification indices and theoretical relevance, three covariance were added (i2-i3, i2-i9, i4-i5) and the results in Table 3 were obtained. According to the results in Table 3, and Figure 3 the model fit indices generally reached a particularly good level and it was determined that factor loads were in appropriate ranges after covariance connections suitable to modification suggestions.

Table 3: Model Fit Indices of Perceived Organizational Support Scale

\begin{tabular}{ccc}
\hline Indices & CFA & CFA $^{*}$ \\
& 10 items and a dimension & 10 items and a dimension \\
\hline $\mathrm{X}^{2} / \mathrm{df}$ & 3.904 & 2.514
\end{tabular}




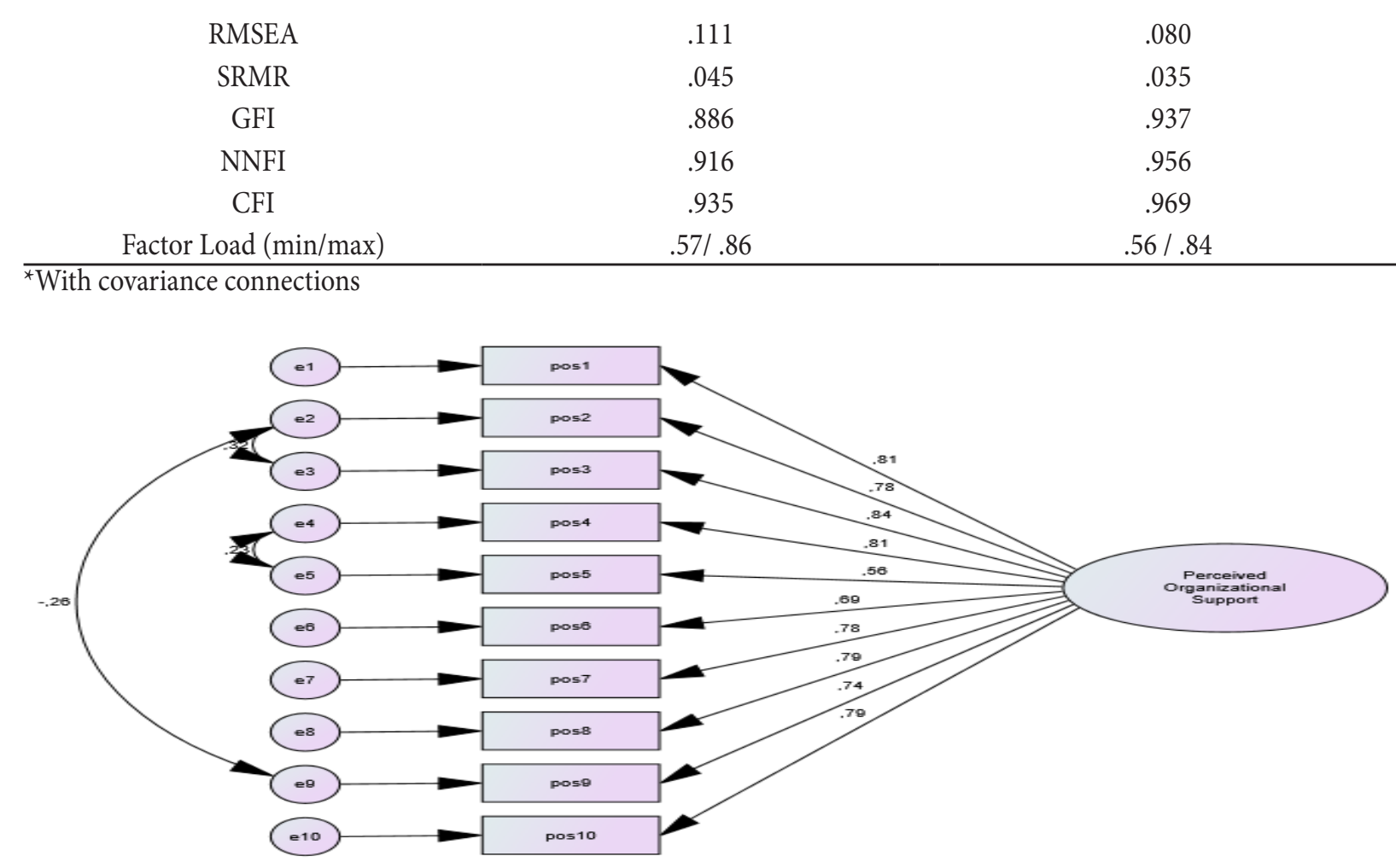

Figure 3: CFA Diagram of Perceived Organizational Support Scale

CFA and item analysis results are shown in Table 4. According to the validity and reliability analysis results in Table 4, it been identified factor loadings of all items were appropriate range in the perceived organizational support scale, and t values are significant at the level of 0.01 . The Cronbach Alpha coefficient of the scale was determined as .93, and the item-total correlation was found to be higher than .30 (between.56 and .81) for all items in the scale. According to validity and reliability analysis, it was determined that the perceived organizational support scale is a reliable and valid scale with its 10 items and one-dimensional structure. 
Table 4: CFA and Item Analysis Results of Perceived Organizational Support Scale

\begin{tabular}{ccccc}
\hline Item & Std. $\beta$ & $\mathrm{t}$ & $\mathrm{r}$ & $\alpha$ \\
\hline 1 & .81 & & .77 & .73 \\
2 & .78 & $13.39^{* *}$ & .81 & \\
3 & .84 & $14.87^{\star *}$ & .79 & \\
4 & .81 & $14.18^{* *}$ & .56 & .93 \\
5 & .56 & $8.89^{* *}$ & .67 & \\
6 & .69 & $11.58^{* *}$ & .75 & \\
7 & .78 & $13.65^{* *}$ & .75 & \\
8 & .79 & $13.68^{* *}$ & .70 & \\
9 & .74 & $12.49^{* *}$ & .76 & \\
10 & .79 & $13.88^{* *}$ & &
\end{tabular}

\subsubsection{Validity and Reliability Analysis Results of the Organizational Dedication Scale}

In the first phase of the CFA performed in accordance with the original structure of the organizational dedication scale (18 items and 3 dimension), it was determined that the factor loads of all items were within the appropriate ranges. But the model fit indices were not at the appropriate levels. On the basis of modification indices and theoretical relevance, two covariance were added. Therefore, covariance connections were made primarily, on the basis of modification indices and theoretical relevance, eight covariance were added (i1-i2, i4-i5, i7-i11, i10-i12, i11-i12, i14-i18, i16-i17, i17-i18) and the results in Table 5 were obtained. Based on the results in Table 5, and Figure 4, the model fit indices generally reached a particularly good level and it was determined that factor loads were in appropriate ranges after covariance connections suitable to modification suggestions.

Table 5: Model Fit Indices of Organizational Dedication Scale

\begin{tabular}{ccc}
\hline Indices & CFA & $\begin{array}{c}\text { CFA }^{*} \\
\text { X }\end{array}$ \\
RMSEA & 18 items and 3 dimensions & 18 items and 3 dimensions \\
\hline SRMR & 3.051 & 2.396 \\
GFI & .093 & .077 \\
NNFI & .051 & .046 \\
CFI & .841 & .893 \\
Factor Load (min/max) & .919 & .945 \\
*With covariance connections & .930 & .955 \\
\end{tabular}

${ }^{*}$ With covariance connections 


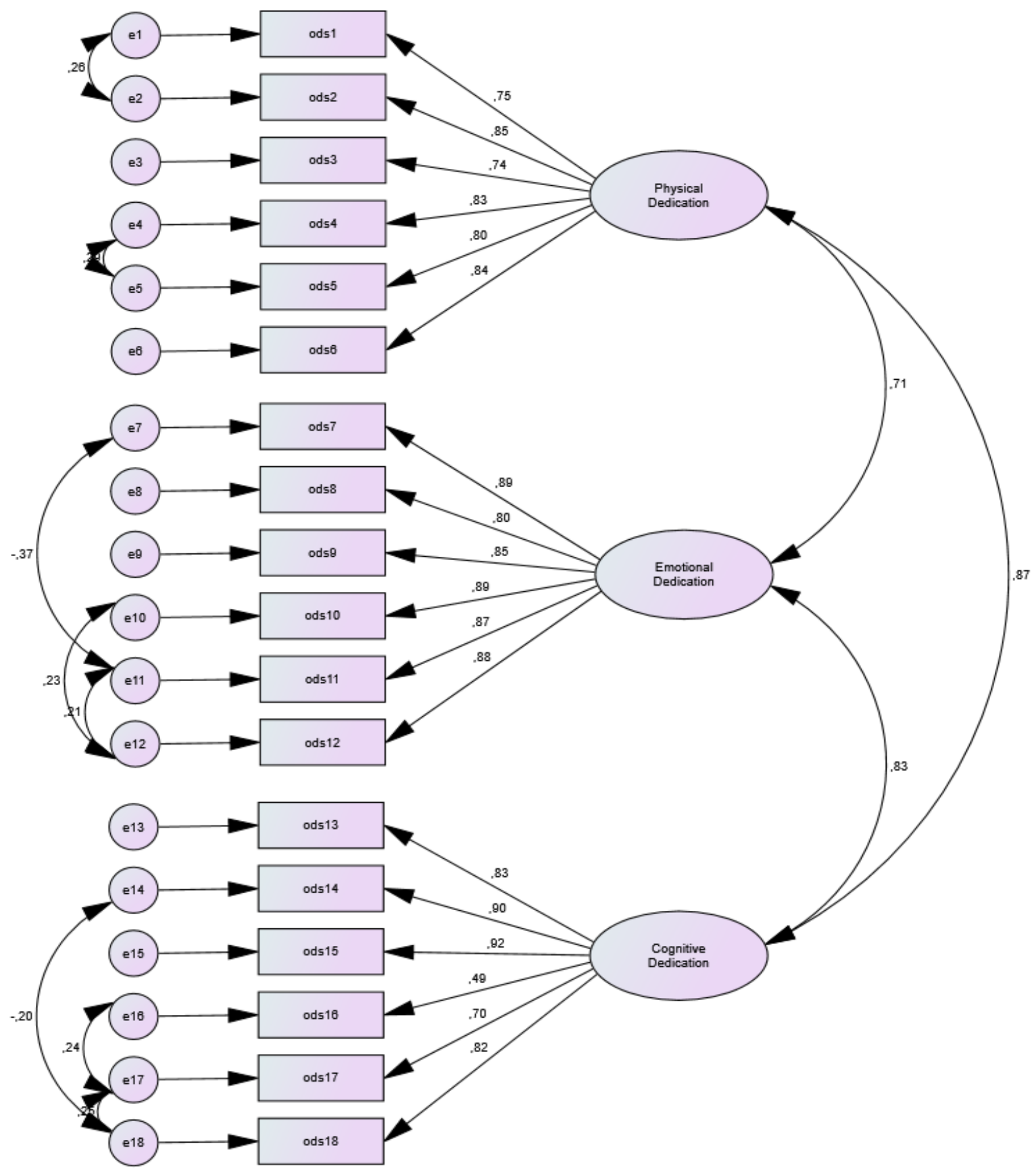

Figure 4: CFA Diagram of Organizational Dedication Scale

CFA and item analysis results are shown in Table 6. According to the validity and reliability analysis results in Table 6, it been identified factor loadings of all items were appropriate range in the organizational dedication scale, and t values are significant at the level of 0.01 . The Cronbach Alpha coefficient of the scale was determined as .96; and the Cronbach Alpha coefficient of the dimensions were determined between .89 and .94 . The item-total correlation was found to be higher than .30 
(between.45 and .86) for all items in the scale. According to validity and reliability analysis, it was determined that the organizational dedication scale is a reliable and valid scale with its 18 items and one-dimensional structure.

Table 6: CFA and Item Analysis Results of Organizational Dedication Scale

\begin{tabular}{|c|c|c|c|c|c|}
\hline Dimension & Item & Std. $\beta$ & $\mathrm{t}$ & $\mathrm{r}$ & $\begin{array}{c}a \\
(.96) \\
\end{array}$ \\
\hline \multirow{6}{*}{$\begin{array}{c}\text { Physical } \\
\text { Dedication }\end{array}$} & 1 & .75 & & .69 & \multirow{6}{*}{.92} \\
\hline & 2 & .85 & $15.43^{* *}$ & .74 & \\
\hline & 3 & .74 & $11.53^{\star *}$ & .61 & \\
\hline & 4 & .83 & $13.03^{\star *}$ & .76 & \\
\hline & 5 & .80 & $12.44^{\star *}$ & .74 & \\
\hline & 6 & .84 & $13.25^{\star *}$ & .73 & \\
\hline \multirow{6}{*}{$\begin{array}{l}\text { Emotional } \\
\text { Dedication }\end{array}$} & 7 & .89 & & .79 & \multirow{6}{*}{.94} \\
\hline & 8 & .80 & $16.00^{* *}$ & .77 & \\
\hline & 9 & .85 & $18.23^{* *}$ & .79 & \\
\hline & 10 & .89 & $19.76^{* *}$ & .76 & \\
\hline & 11 & .87 & $16.30^{\star *}$ & .75 & \\
\hline & 12 & .88 & $18.99^{\star *}$ & .76 & \\
\hline \multirow{6}{*}{$\begin{array}{l}\text { Cognitive } \\
\text { Dedication }\end{array}$} & 13 & .83 & & .80 & \multirow{6}{*}{.89} \\
\hline & 14 & .90 & $18.08^{* *}$ & .85 & \\
\hline & 15 & .92 & $18.69^{\star *}$ & .86 & \\
\hline & 16 & .49 & $7.89^{\star *}$ & .45 & \\
\hline & 17 & .70 & $12.17^{* *}$ & .67 & \\
\hline & 18 & .82 & $15.31^{* *}$ & .78 & \\
\hline
\end{tabular}

\subsection{Sample of the Study}

Frequency and percentage distribution according to the demographic characteristics of the participants are shown in Table 7.

Table 7: Distribution of Participants According to Demographic Features

\begin{tabular}{cccc}
\hline Demographic Variable & Groups & $\mathrm{n}$ & $\%$ \\
\hline \multirow{2}{*}{ Gender } & Female & 142 & 59.9 \\
& Male & 95 & 40.1 \\
Marital status & The married & 89 & 37.6 \\
& Single & 148 & 62.4 \\
Age (generation) & Generation X (1965-1979) & 46 & 19.4
\end{tabular}




\begin{tabular}{cccc} 
& High school & 65 & 27.4 \\
Education level & Associate degree & 71 & 30.0 \\
& Undergraduate degree & 75 & 31.6 \\
& Graduate & 26 & 11.0 \\
Working period in this & Less than 1 year & 49 & 20.7 \\
organization & $1-3$ years & 80 & 33.8 \\
& 4 years and above & 108 & 45.6 \\
Position & Non-executive & 172 & 72.6 \\
& Manager & 65 & 27.4 \\
Working period in this & Less than 1 year & 50 & 21.1 \\
position & $1-3$ years & 84 & 35.4 \\
& 4 years and above & 103 & 43.5 \\
& Less than 2 years & 47 & 19.8 \\
Total working period & $3-5$ years & 65 & 27.4 \\
& $6-10$ years & 39 & 16.5 \\
Total number of employees & 11 years and above & 86 & 36.3 \\
in this organization & 1000 people & 82 & 34.6 \\
& $1000-3000$ people & 101 & 42.6 \\
\hline
\end{tabular}

Participating in the research $(\mathrm{N}=237), 59.9 \%$ are female and $40.1 \%$ are male. $37.6 \%$ of the participants are married and $62.4 \%$ are single. $37.6 \%$ of the participants are married and $62.4 \%$ are single.

There are different generation classifications made by different researchers. Oblinger \& Oblinger (2005) classification which is often used in Turkey is used in our research. 19.4\% of the participants are in the X generation (1965-1979) and 80.6\% in the Y generation (1980-1999) group. $27.4 \%$ of the participants studied at high school, $30 \%$ at associate degree, $31.6 \%$ at undergraduate degree and $11 \%$ at graduate level. Working period of $20.7 \%$ of the participants are less than 1 year, $33.8 \%$ of them are $1-3$ years, $45.6 \%$ of them are 4 years and above in the organization. $27.4 \%$ of the participants are executive in the organization. Working period of $21.1 \%$ of the participants are less than 1 year, $35.4 \%$ of them are 1-3 years, $43.5 \%$ of them are 4 years and above in the position. Total working period of $19.8 \%$ of the participants are less than 2 year, $27.4 \%$ of them are $3-5$ years, $16.5 \%$ of them are $6-10$ years, $36.3 \%$ of them are 1 years and above. Total number of employees of $34.6 \%$ of the participants are less than 1000 people, $42.6 \%$ of them are $1000-3000$ people, $22.8 \%$ of them are 3001 people and above in the organization.

\subsection{Analysis of Data}

Confirmatory factor analysis method within the scope of validity of the scales, item analysis (inter item correlations, Cronbach Alpha) method within the scope of the reliability was used.

Confirmatory factor analysis (CFA) is a highly advanced technique based on testing theories about latent variables and used in advanced research. It is an analysis in which a previously defined and 
restricted structure is tested as to whether it is validated as a model. Common used are "The ratio of chi-square statistics to degree of freedom (X2 / sd)", "Statistical significance of the individual parameter estimation (t value)", "Residual fit indexes (SRMR, GFI)", "fit indices based on independent model (NFI, NNFI, CFI)", and "Root mean square error of approximation (RMSEA)" fit indices to evaluate model fit in structural equation models (Çokluk, Şekercioğlu \& Büyüköztürk, 2010). Expected coefficients for the model fit indices are shown in Table 8.

Table 8. Model Fit Indices

\begin{tabular}{ccc}
\hline Indices & Good & Perfect Good \\
\hline $\mathrm{X}^{2} / \mathrm{df}$ & $<5$ & $<3$ \\
RMSEA & $\leq .10$ & $<.08$ \\
SRMR & $\leq .08$ & $<.05$ \\
GFI & $\geq .90$ & $>.95$ \\
NFI & $\geq .90$ & $>.95$ \\
NNFI & $\geq .90$ & $>.95$ \\
CFI & $\geq .90$ & $>.95$ \\
\hline
\end{tabular}

Source: Çokluk, Şekercioğlu \& Büyüköztürk, 2010.

Cronbach Alpha technique is used as an item analysis method to examine the consistency between test scores. Cronbach Alpha shows internal consistency and is generally expected to be above.70. The item total correlation used in is another item analysis method in order to explain the relationship between the scores obtained from the test items and the total score of the test. Item-total correlation 0.30 and higher can be said to distinguish individuals well, if it is between .20 and .30 , it can be taken to the test if necessary. Both tests show that the items in the measuring tool exemplify similar behaviors and that the test has internal consistency (Büyüköztürk, 2011).

Pearson's correlation was examined to determine the effect of perceived organizational support on organizational depression and organizational dedication. The path analysis was established within the scope of the structural equation model since the correlation relationship was found to be significant. The skewness coefficient was used in the normality test of the test scores. Skewness score remains within \pm 1 , showing that data are normally distributed (Büyüköztürk, 2011). Independent two sample $t$ tests were used in the comparison of scale and sub-dimension scores according to gender, marital status, birth belt, and position in the organization variables because it was determined that the scale and subscale scores showed normal distribution. One way ANOVA were used in the comparison of scale and sub-dimension scores according to education level, working period in this organization, working period in this position, total working period, total number of employees in this organization variables because it was determined that the scale and subscale scores showed normal distribution. LSD post hoc test was used, when there was a significant difference in ANOVA test to determine which groups the difference is between. The 95\% confidence interval was determined (significance level $.05 / \mathrm{p}<.05)$ in the analyzes. 


\subsection{Findings}

\subsubsection{Descriptive Findings}

Descriptive statistics of scale and subscale scores are shown in Table 9. According to Table 9, it was

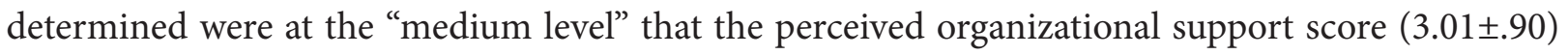

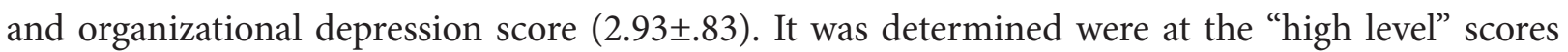

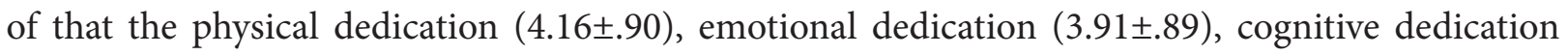

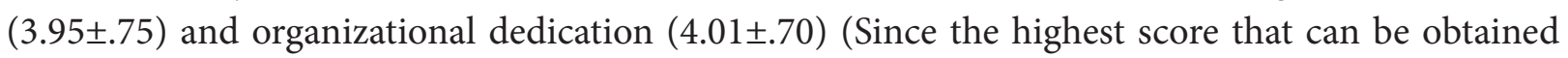
from the scale is 5 - the lowest score is $=1$, the range of scores is $5-1=4$; and breakpoint is $4 / 5=$ 0.80; score levels assumed to: 1.00-1.80: very low; 1.81-2.60: low; 2.61-3.40: medium; 3.41-4.20: high; 4.21-5.00: very high).

Table 9. Descriptive Statistics for Scale and Sub-Dimension Scores

\begin{tabular}{|c|c|c|c|c|c|c|}
\hline Variables & $\mathrm{n}$ & Min. & Max. & $\overline{\mathrm{x}}$ & $\mathrm{SD}$ & Skewness \\
\hline PERCEIVED ORGANIZATIONAL SUPPORT & 237 & 1.00 & 5.00 & 3.01 & .90 & -.32 \\
\hline ORGANIZATIONAL DEPRESSION & 237 & 1.04 & 5.00 & 2.93 & .83 & .18 \\
\hline Physical Dedication & 237 & 1.33 & 5.00 & 4.16 & .70 & -.81 \\
\hline Emotional Dedication & 237 & 1.00 & 5.00 & 3.91 & .89 & -.59 \\
\hline Cognitive Dedication & 237 & 1.00 & 5.00 & 3.95 & .75 & -.53 \\
\hline ORGANIZATIONAL DEDICATION & 237 & 1.11 & 5.00 & 4.01 & .70 & -.54 \\
\hline
\end{tabular}

\subsubsection{Findings Related to the Research Model}

In Table 10, results are given to Pearson correlation analysis of the relationship between the scale and sub-dimension scores. According to the results in Table 10, it was determined that there is a negative and significant relationship $(\mathrm{r}=-.78 ; \mathrm{p}<.05)$ between the scores of the independent variable (perceived organizational support) of the research and the scores of the dependent variable (organizational depression).

Table 10: Correlation Analysis Between Variables

\begin{tabular}{|c|c|c|c|c|c|}
\hline Variables & 2 & 3 & 4 & 5 & 6 \\
\hline 1. PERCEIVED ORGANIZATIONAL SUPPORT & $-.78^{* \star}$ & $.23^{* *}$ & $.48^{* *}$ & $.36^{* *}$ & $.41^{* *}$ \\
\hline 2. ORGANIZATIONAL DEPRESSION & 1 & $-.24^{* *}$ & $-.50^{* *}$ & $-.34^{\star *}$ & $-.42^{* *}$ \\
\hline 3. Physical Dedication & & 1 & $.65^{\star *}$ & $.76^{\star *}$ & $.88^{* *}$ \\
\hline 4. Emotional Dedication & & & 1 & $.74^{* *}$ & $.90^{* *}$ \\
\hline 5. Cognitive Dedication & & & & 1 & $.92^{\star *}$ \\
\hline 6. ORGANIZATIONAL DEDICATION & & & & & 1 \\
\hline
\end{tabular}


It was determined that there is a positive and significant relationship between the scores of independent variable (perceived organizational support) of the research and physical dedication $(r=.23 ; p<.05)$, emotional dedication $(r=.48 ; \mathrm{p}<.05)$, cognitive dedication $(\mathrm{r}=.36 ; \mathrm{p}<.05)$, organizational dedication $(\mathrm{r}=.41 ; \mathrm{p}<.05)$ variables (Table 10$)$.

In the research model were defined perceived organizational support is which as independent variable, and organizational depression and organizational dedication as dependent variables (Figure $5)$.

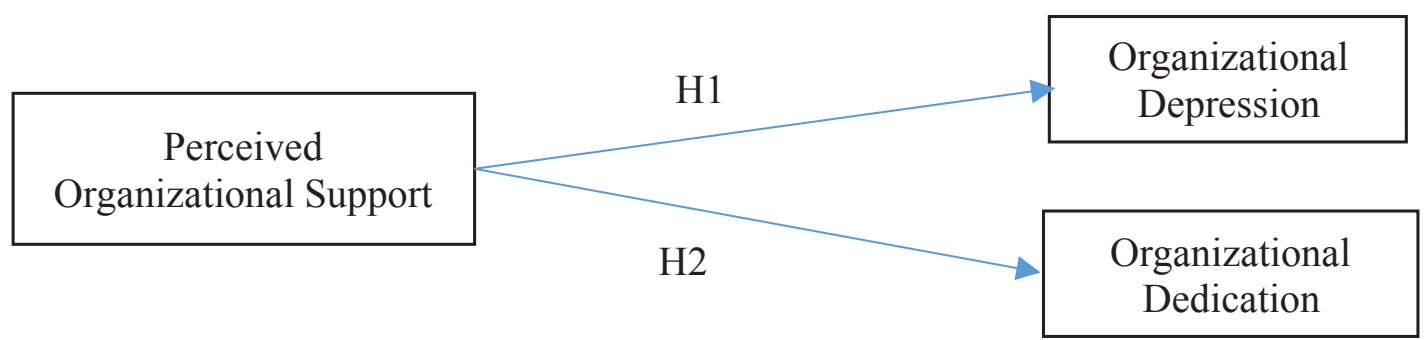

Figure 5: Research Model

The path analysis findings of research model (Figure 5) are shown in Table 11.

Table 11: Findings Related to the Research Model

\begin{tabular}{|c|c|c|c|c|c|c|}
\hline Hypothesis & Independent Variable & Path & Dependent Variable & $\begin{array}{c}\beta \\
(\mathrm{SE}) \\
\end{array}$ & $\mathrm{t}$ & $\mathrm{R}^{2}$ \\
\hline H1 & \multirow{2}{*}{$\begin{array}{c}\text { Perceived Organizational } \\
\text { Support }\end{array}$} & $\rightarrow$ & Organizational Depression & $\begin{array}{l}-.84 \\
(.07)\end{array}$ & $-8,89^{* *}$ & .71 \\
\hline $\mathrm{H} 2$ & & $\rightarrow$ & Organizational Dedication & $\begin{array}{c}.44 \\
(.04)\end{array}$ & $6,18^{* *}$ & .19 \\
\hline \multicolumn{7}{|c|}{$\mathrm{X}^{2}$ /df: 2.00 RMSEA: .06 SRMR: .06 GFI: .77 NNFI:.90 CFI:.90 } \\
\hline
\end{tabular}

According to Table 11, the results of the hypothesis were determined as follows:

H1 Accepted: The perceived organizational support has a negative and significant effect on organizational depression $(\beta=-.84 ; \mathrm{t}=-8.89 ; \mathrm{p}<.05)$.

H2 Accepted: The perceived organizational support has a positive and significant effect on organizational dedication $(\beta=.44 ; \mathrm{t}=6.18 ; \mathrm{p}<.05)$. 


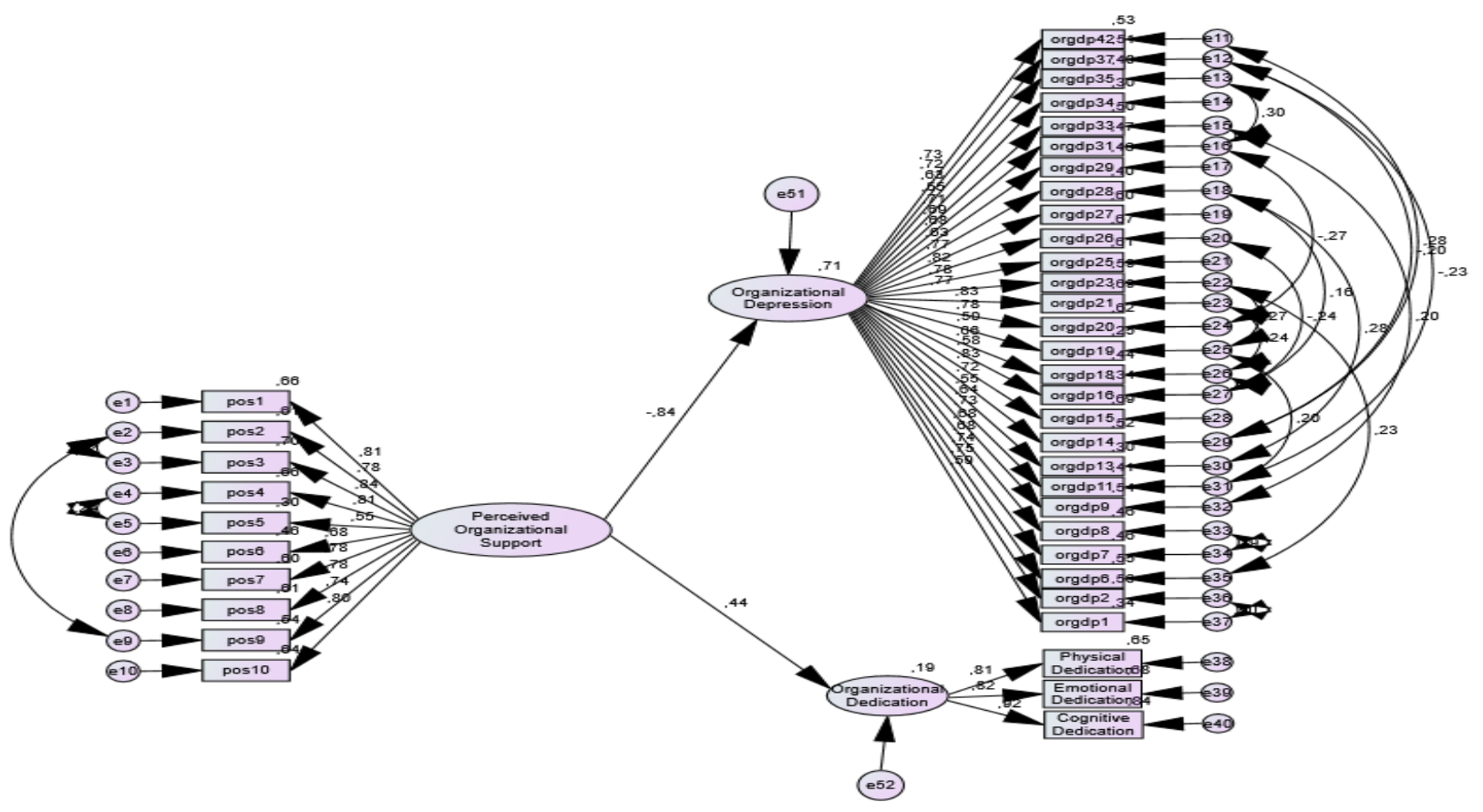

Figure 6: Path Diagram of Research Model

3.4.3. Findings Related to the Comparison of Scale Scores According to Demographic Variables

Table 12: Comparison of Scale Scores According to Gender

\begin{tabular}{|c|c|c|c|c|c|c|}
\hline Scale and Dimension & Gender & $\mathrm{n}$ & $\overline{\mathrm{x}}$ & SD & $t$ & p \\
\hline \multirow{2}{*}{ PERCEIVED ORGANIZATIONAL SUPPORT } & Female & 142 & 2.97 & .87 & \multirow{2}{*}{-.85} & \multirow{2}{*}{.399} \\
\hline & Male & 95 & 3.07 & .95 & & \\
\hline \multirow{2}{*}{ ORGANIZATIONAL DEPRESSION } & Female & 142 & 2.94 & .80 & \multirow{2}{*}{.27} & \multirow{2}{*}{.787} \\
\hline & Male & 95 & 2.91 & .87 & & \\
\hline \multirow{2}{*}{ Physical Dedication } & Female & 142 & 4.17 & .63 & \multirow{2}{*}{.41} & \multirow{2}{*}{.682} \\
\hline & Male & 95 & 4.14 & .79 & & \\
\hline \multirow{2}{*}{ Emotional Dedication } & Female & 142 & 3.95 & .81 & \multirow{2}{*}{.99} & \multirow{2}{*}{.319} \\
\hline & Male & 95 & 3.84 & .99 & & \\
\hline \multirow{2}{*}{ Cognitive Dedication } & Female & 142 & 3.99 & .65 & \multirow{2}{*}{.97} & \multirow{2}{*}{.332} \\
\hline & Male & 95 & 3.89 & .88 & & \\
\hline \multirow{2}{*}{ ORGANIZATIONAL DEDICATION } & Female & 142 & 4.04 & .61 & \multirow{2}{*}{.90} & \multirow{2}{*}{.367} \\
\hline & Male & 95 & 3.96 & .82 & & \\
\hline
\end{tabular}

The perception of organizational support, organizational depression and organizational dedication score were not found to differ significantly by gender ( $\mathrm{p}>0.05$ ) (Table 12). 
Table 13 shows the independent sample t-test result of comparing the scale scores according to marital status.

Table 13: Comparison of Scale Scores According to Marital Status

\begin{tabular}{|c|c|c|c|c|c|c|}
\hline Scale and Dimension & Marital Status & $\mathrm{n}$ & $\overline{\mathrm{X}}$ & SD & $\mathrm{t}$ & $\mathrm{p}$ \\
\hline \multirow{2}{*}{ PERCEIVED ORGANIZATIONAL SUPPORT } & Married & 89 & 2.92 & .88 & \multirow{2}{*}{-1.20} & \multirow{2}{*}{.232} \\
\hline & Single & 148 & 3.06 & .91 & & \\
\hline \multirow{2}{*}{ ORGANIZATIONAL DEPRESSION } & Married & 89 & 3.00 & .69 & \multirow{2}{*}{.94} & \multirow{2}{*}{.349} \\
\hline & Single & 148 & 2.89 & .90 & & \\
\hline \multirow{2}{*}{ Physical Dedication } & Married & 89 & 4.24 & .61 & \multirow{2}{*}{1.37} & \multirow{2}{*}{.172} \\
\hline & Single & 148 & 4.11 & .74 & & \\
\hline \multirow{2}{*}{ Emotional Dedication } & Married & 89 & 3.96 & .80 & \multirow{2}{*}{.74} & \multirow{2}{*}{.457} \\
\hline & Single & 148 & 3.87 & .93 & & \\
\hline \multirow{2}{*}{ Cognitive Dedication } & Married & 89 & 4.03 & .74 & \multirow{2}{*}{1.16} & \multirow{2}{*}{.246} \\
\hline & Single & 148 & 3.91 & .76 & & \\
\hline \multirow{2}{*}{ ORGANIZATIONAL DEDICATION } & Married & 89 & 4.08 & .64 & \multirow{2}{*}{1.18} & \multirow{2}{*}{.238} \\
\hline & Single & 148 & 3.96 & .74 & & \\
\hline
\end{tabular}

The results in the perception of organizational support, organizational depression and organizational dedication score were not found to differ significantly by marital status ( $\mathrm{p}>0.05)$ (Table 13).

Table 14 shows the independent sample t-test result of comparing the scale scores according to generations.

Table 14: Comparison of Scale Scores According to Generations

\begin{tabular}{|c|c|c|c|c|c|c|}
\hline Scale and Dimension & Generation & $\mathrm{n}$ & $\overline{\mathrm{x}}$ & SD & $\mathrm{t}$ & $\mathrm{p}$ \\
\hline \multirow{2}{*}{ PERCEIVED ORGANIZATIONAL SUPPORT } & X (1965-1979) & 46 & 3,00 & 0,80 & \multirow{2}{*}{$-0,07$} & \multirow{2}{*}{0,946} \\
\hline & Y (1980-1979) & 191 & 3,01 & 0,92 & & \\
\hline \multirow{2}{*}{ ORGANIZATIONAL DEPRESSION } & X (1965-1979) & 46 & 3,04 & 0,79 & \multirow{2}{*}{0,99} & \multirow{2}{*}{0,321} \\
\hline & Y (1980-1979) & 191 & 2,90 & 0,84 & & \\
\hline \multirow{2}{*}{ Physical Dedication } & $\mathrm{X}(1965-1979)$ & 46 & 4,21 & 0,69 & \multirow{2}{*}{0,51} & \multirow{2}{*}{0,613} \\
\hline & $\mathrm{Y}(1980-1979)$ & 191 & 4,15 & 0,70 & & \\
\hline \multirow{2}{*}{ Emotional Dedication } & $\mathrm{X}(1965-1979)$ & 46 & 4,01 & 0,75 & \multirow{2}{*}{0,91} & \multirow{2}{*}{0,361} \\
\hline & Y (1980-1979) & 191 & 3,88 & 0,92 & & \\
\hline \multirow{2}{*}{ Cognitive Dedication } & X (1965-1979) & 46 & 3,94 & 0,78 & \multirow{2}{*}{$-0,14$} & \multirow{2}{*}{0,885} \\
\hline & Y (1980-1979) & 191 & 3,96 & 0,75 & & \\
\hline \multirow{2}{*}{ ORGANIZATIONAL DEDICATION } & X (1965-1979) & 46 & 4,05 & 0,67 & \multirow{2}{*}{0,50} & \multirow{2}{*}{0,617} \\
\hline & Y (1980-1979) & 191 & 4,00 & 0,71 & & \\
\hline
\end{tabular}

The perception of organizational support, organizational depression and organizational dedication score were not found to differ significantly by generation $(\mathrm{p}>0.05)$ (Table 14). 
Table 15 shown the one-way ANOVA test result of comparing the scale scores according to education level.

Table 15: Comparison of Scale Scores According to Education Level

\begin{tabular}{|c|c|c|c|c|c|c|c|}
\hline Scale and Dimension & $\begin{array}{l}\text { Education } \\
\text { Level }\end{array}$ & $\mathrm{n}$ & $\overline{\mathrm{x}}$ & $\mathrm{SD}$ & $\mathrm{n}$ & $\mathrm{p}$ & $\begin{array}{l}\text { Significant } \\
\text { Difference }\end{array}$ \\
\hline \multirow{4}{*}{$\begin{array}{l}\text { PERCEIVED ORGANIZATIONAL } \\
\text { SUPPORT }\end{array}$} & A-High school & 65 & 3.10 & .89 & \multirow{4}{*}{2.93} & \multirow{4}{*}{.035} & $A, B>D$ \\
\hline & B-Associate degree & 71 & 3.17 & .93 & & & \\
\hline & C-Undergraduate degree & 75 & 2.89 & .90 & & & \\
\hline & D-Graduate & 26 & 2.65 & .72 & & & \\
\hline \multirow{4}{*}{ ORGANIZATIONAL DEPRESSION } & High school & 65 & 2.83 & .77 & \multirow{4}{*}{6.76} & \multirow{4}{*}{.000} & C, D $>A, B$ \\
\hline & Associate degree & 71 & 2.67 & .90 & & & \\
\hline & Undergraduate degree & 75 & 3.12 & .73 & & & \\
\hline & Graduate & 26 & 3.36 & .79 & & & \\
\hline \multirow{4}{*}{ Physical Dedication } & High school & 65 & 4.19 & .78 & \multirow{4}{*}{1.29} & \multirow{4}{*}{.279} & \\
\hline & Associate degree & 71 & 4.26 & .70 & & & \\
\hline & Undergraduate degree & 75 & 4.10 & .63 & & & \\
\hline & Graduate & 26 & 3.98 & .66 & & & \\
\hline \multirow{4}{*}{ Emotional Dedication } & High school & 65 & 3.94 & .94 & \multirow{4}{*}{5.42} & \multirow{4}{*}{.001} & $A>D$ \\
\hline & Associate degree & 71 & 4.19 & .81 & & & $\mathrm{~B}>\mathrm{C}, \mathrm{D}$ \\
\hline & Undergraduate degree & 75 & 3.77 & .82 & & & \\
\hline & Graduate & 26 & 3.47 & .94 & & & \\
\hline \multirow{4}{*}{ Cognitive Dedication } & High school & 65 & 3.96 & .84 & \multirow{4}{*}{1.85} & \multirow{4}{*}{.139} & \\
\hline & Associate degree & 71 & 4.10 & .67 & & & \\
\hline & Undergraduate degree & 75 & 3.88 & .73 & & & \\
\hline & Graduate & 26 & 3.74 & .80 & & & \\
\hline \multirow{4}{*}{ ORGANIZATIONAL DEDICATION } & High school & 65 & 4.03 & .78 & \multirow{4}{*}{3.37} & \multirow{4}{*}{.019} & $\mathrm{~B}>\mathrm{C}, \mathrm{D}$ \\
\hline & Associate degree & 71 & 4.18 & .67 & & & \\
\hline & Undergraduate degree & 75 & 3.92 & .64 & & & \\
\hline & Graduate & 26 & 3.73 & .67 & & & \\
\hline
\end{tabular}

Perceived organizational support $(\mathrm{F}=2.93 ; \mathrm{p}<0.05)$, organizational depression $(\mathrm{F}=6.76 ; \mathrm{p}<0.05)$, emotional dedication $(F=5.42 ; \mathrm{p}<0.05)$, organizational dedication $(\mathrm{F}=3.37 ; \mathrm{p}<0.05)$ scores were found to differ significantly by education level. According to results of LSD post hoc test (Table 15);

- Perceived organizational support scores of participants who study at high school and associate level is significantly higher than the scores of participants who study at graduate level.

- Organizational depression scores of participants who study at associate degree and undergraduate degree level is significantly higher than the scores of participants who study at high school and associate degree level.

- Emotional dedication scores of participants who study at high school level is significantly higher than the scores of participants who study at graduate level. Emotional dedication scores 
of participants who study at associate degree level is significantly higher than the scores of participants who study at undergraduate degree and graduate level.

- Organizational dedication scores of participants who study at associate degree level is significantly higher than the scores of participants who study at undergraduate degree and graduate level.

Physical and cognitive dedication scores were not found to differ significantly by education level.

Table 16 shows the one-way ANOVA test result of comparing the scale scores according to working period in this organization.

Table 16: Comparison of Scale Scores According to Working Period in This Organization

\begin{tabular}{|c|c|c|c|c|c|c|c|}
\hline Scale and Dimension & $\begin{array}{l}\text { Working Period in This } \\
\text { Organization }\end{array}$ & $\mathrm{n}$ & $\overline{\mathrm{x}}$ & $\mathrm{SD}$ & $n$ & $\mathrm{p}$ & $\begin{array}{l}\text { Significant } \\
\text { Difference }\end{array}$ \\
\hline \multirow{3}{*}{$\begin{array}{l}\text { PERCEIVED } \\
\text { ORGANIZATIONAL SUPPORT }\end{array}$} & A-Less than 1 year & 49 & 3.36 & .95 & \multirow{3}{*}{4.99} & \multirow{3}{*}{.008} & $\mathrm{~A}>\mathrm{B}, \mathrm{C}$ \\
\hline & B-1-3 years & 80 & 2.89 & .88 & & & \\
\hline & C-4 years and above & 108 & 2.93 & .86 & & & \\
\hline \multirow{3}{*}{$\begin{array}{l}\text { ORGANIZATIONAL } \\
\text { DEPRESSION }\end{array}$} & A-Less than 1 year & 49 & 2.51 & .94 & \multirow{3}{*}{8.39} & \multirow{3}{*}{.000} & $\mathrm{~B}, \mathrm{C}>\mathrm{A}$ \\
\hline & B-1-3 years & 80 & 3.05 & .87 & & & \\
\hline & C-4 years and above & 108 & 3.03 & .68 & & & \\
\hline \multirow{3}{*}{ Physical Dedication } & A-Less than 1 year & 49 & 4.30 & .70 & \multirow{3}{*}{1.30} & \multirow{3}{*}{.275} & \\
\hline & B-1-3 years & 80 & 4.12 & .67 & & & \\
\hline & C- 4 years and above & 108 & 4.12 & .71 & & & \\
\hline \multirow{3}{*}{ Emotional Dedication } & A-Less than 1 year & 49 & 4.12 & .80 & \multirow{3}{*}{1.83} & \multirow{3}{*}{.162} & \\
\hline & B-1-3 years & 80 & 3.83 & .93 & & & \\
\hline & C-4 years and above & 108 & 3.87 & .89 & & & \\
\hline \multirow{3}{*}{ Cognitive Dedication } & A-Less than 1 year & 49 & 4.24 & .75 & \multirow{3}{*}{4.76} & \multirow{3}{*}{.009} & $A>B, C$ \\
\hline & B-1-3 years & 80 & 3.85 & .75 & & & \\
\hline & C-4 years and above & 108 & 3.90 & .73 & & & \\
\hline \multirow{3}{*}{$\begin{array}{l}\text { ORGANIZATIONAL } \\
\text { DEDICATION }\end{array}$} & A-Less than 1 year & 49 & 4.22 & .69 & \multirow{3}{*}{2.97} & \multirow{3}{*}{.053} & \\
\hline & B-1-3 years & 80 & 3.93 & .71 & & & \\
\hline & C-4 years and above & 108 & 3.96 & .69 & & & \\
\hline
\end{tabular}

Perceived organizational support $(\mathrm{F}=4.99 ; \mathrm{p}<0.05)$, organizational depression $(\mathrm{F}=8.39 ; \mathrm{p}<0.05)$, emotional dedication $(\mathrm{F}=4.76 ; \mathrm{p}<0.05)$ scores were found to differ significantly by working period in this organization. According to results of LSD post hoc test (Table 16);

- Perceived organizational support and organizational dedication scores of participants who working period in this organization less than 1 year is significantly higher than the scores of participants who 1 years and above working period.

- Organizational depression scores of participants who working period in this organization 1 year and above is significantly higher than the scores of participants who less than 1year period. 
According to the results in Table 16, physical, emotional and organizational dedication scores were not found to differ significantly by working period in this organization.

Table 17 shows the independent sample t-test result of comparing the scale scores according to position in business.

Table 17: Comparison of Scale Scores According to Position in Business

\begin{tabular}{|c|c|c|c|c|c|c|}
\hline Scale and Dimension & Position in Business & $\mathrm{n}$ & $\overline{\mathrm{x}}$ & SD & $\mathrm{t}$ & $\mathrm{p}$ \\
\hline \multirow{2}{*}{ PERCEIVED ORGANIZATIONAL SUPPORT } & Non manager & 172 & 3.04 & .92 & \multirow{2}{*}{.82} & \multirow{2}{*}{.411} \\
\hline & Manager & 65 & 2.93 & .85 & & \\
\hline \multirow{2}{*}{ ORGANIZATIONAL DEPRESSION } & Non manager & 172 & 2.89 & .86 & \multirow{2}{*}{-1.06} & \multirow{2}{*}{.289} \\
\hline & Manager & 65 & 3.02 & .74 & & \\
\hline \multirow{2}{*}{ Physical Dedication } & Non manager & 172 & 4.18 & .71 & \multirow{2}{*}{.84} & \multirow{2}{*}{.401} \\
\hline & Manager & 65 & 4.10 & .68 & & \\
\hline \multirow{2}{*}{ Emotional Dedication } & Non manager & 172 & 3.92 & .94 & \multirow{2}{*}{.24} & \multirow{2}{*}{.810} \\
\hline & Manager & 65 & 3.88 & .74 & & \\
\hline \multirow{2}{*}{ Cognitive Dedication } & Non manager & 172 & 3.97 & .77 & \multirow{2}{*}{.63} & \multirow{2}{*}{.528} \\
\hline & Manager & 65 & 3.90 & .70 & & \\
\hline \multirow{2}{*}{ ORGANIZATIONAL DEDICATION } & Non manager & 172 & 4.02 & .74 & \multirow{2}{*}{.61} & \multirow{2}{*}{.545} \\
\hline & Manager & 65 & 3.96 & .61 & & \\
\hline
\end{tabular}

The perception of organizational support, organizational depression and organizational dedication score were not found to differ significantly by position in business ( $\mathrm{p}>0.05$ ) (Table 17).

Table 18 shows the one-way ANOVA test result of comparing the scale scores according to Working period in this position.

Table 18: Comparison of Scale Scores According to Working Period in This Position

\begin{tabular}{|c|c|c|c|c|c|c|c|}
\hline Scale and Dimension & $\begin{array}{l}\text { Working Period in This } \\
\text { Position }\end{array}$ & $\mathrm{n}$ & $\overline{\mathrm{x}}$ & $\mathrm{SD}$ & $\mathrm{n}$ & $\mathrm{p}$ & $\begin{array}{l}\text { Significant } \\
\text { Difference }\end{array}$ \\
\hline \multirow{3}{*}{$\begin{array}{c}\text { PERCEIVED } \\
\text { ORGANIZATIONAL } \\
\text { SUPPORT } \\
\end{array}$} & A-Less than 1 year & 50 & 3.39 & .85 & \multirow{3}{*}{6.26} & \multirow{3}{*}{.002} & $\mathrm{~A}>\mathrm{B}, \mathrm{C}$ \\
\hline & B-1-3 years & 84 & 2.94 & .81 & & & \\
\hline & $\mathrm{C}-4$ years and above & 103 & 2.87 & .94 & & & \\
\hline \multirow{3}{*}{$\begin{array}{c}\text { ORGANIZATIONAL } \\
\text { DEPRESSION }\end{array}$} & A-Less than 1 year & 50 & 2.48 & .86 & \multirow{3}{*}{10.28} & \multirow{3}{*}{.000} & $\mathrm{~B}, \mathrm{C}>\mathrm{A}$ \\
\hline & B-1-3 years & 84 & 3.04 & .82 & & & \\
\hline & $\mathrm{C}-4$ years and above & 103 & 3.06 & .75 & & & \\
\hline \multirow{3}{*}{ Physical Dedication } & A-Less than 1 year & 50 & 4.30 & .68 & \multirow{3}{*}{1.52} & \multirow{3}{*}{.220} & \\
\hline & B-1-3 years & 84 & 4.08 & .68 & & & \\
\hline & $\mathrm{C}-4$ years and above & 103 & 4.16 & .72 & & & \\
\hline \multirow{3}{*}{ Emotional Dedication } & A-Less than 1 year & 50 & 4.14 & .83 & \multirow{3}{*}{2.43} & \multirow{3}{*}{.090} & \\
\hline & B-1-3 years & 84 & 3.80 & .85 & & & \\
\hline & $\mathrm{C}-4$ years and above & 103 & 3.88 & .93 & & & \\
\hline
\end{tabular}




\begin{tabular}{cccccccc}
\hline & A-Less than 1 year & 50 & 4.24 & .71 & & A $>$ B, C \\
Cognitive Dedication & B-1-3 years & 84 & 3.85 & .72 & 4.95 & .008 & \\
& C - - 4 years and above & 103 & 3.89 & .78 & & & A $>$ B, C \\
\hline \multirow{2}{*}{ ORGANIZATIONAL } & A-Less than 1 year & 50 & 4.23 & .68 & & & \\
DEDICATION & B-1-3 years & 84 & 3.91 & .68 & 3.40 & .035 & \\
& C - - years and above & 103 & 3.98 & .71 & & & \\
\hline
\end{tabular}

Perceived organizational support $(\mathrm{F}=6.26 ; \mathrm{p}<0.05)$, organizational depression $(\mathrm{F}=10.28 ; \mathrm{p}<0.05)$, cognitive dedication $(\mathrm{F}=4.95 ; \mathrm{p}<0.05)$, organizational dedication $(\mathrm{F}=3.40 ; \mathrm{p}<0.05)$ scores were found to differ significantly by working period in this organization. According to results of LSD post hoc test (Table 18);

- Perceived organizational support, cognitive dedication and organizational dedication scores of participants who working period in this position less than 1 year is significantly higher than the scores of participants who 1 years and above working period.

- Organizational depression scores of participants who working period in this position 1 year and above is significantly higher than the scores of participants who less than 1year period.

Physical and emotional dedication scores were not found to differ significantly by working period in this position (Table 18).

Table 19 shows the one-way ANOVA test result of comparing the scale scores according to total working period

Table 19: Comparison of Scale Scores According to Total Working Period

\begin{tabular}{|c|c|c|c|c|c|c|c|}
\hline Scale and Dimension & Total Working Period & $\mathrm{n}$ & $\overline{\mathrm{X}}$ & SD & $\mathrm{n}$ & $\mathrm{p}$ & $\begin{array}{l}\text { Significant } \\
\text { Difference }\end{array}$ \\
\hline \multirow{4}{*}{$\begin{array}{l}\text { PERCEIVED } \\
\text { ORGANIZATIONAL } \\
\text { SUPPORT }\end{array}$} & A-Less than 2 years & 47 & 3.54 & .77 & \multirow{4}{*}{7.40} & \multirow{4}{*}{.000} & $A>B, C, D$ \\
\hline & B-3-5 years & 65 & 2.84 & .89 & & & \\
\hline & C-6-10 years & 39 & 2.90 & .77 & & & \\
\hline & D-11 years and above & 86 & 2.89 & .93 & & & \\
\hline \multirow{4}{*}{$\begin{array}{l}\text { ORGANIZATIONAL } \\
\text { DEPRESSION }\end{array}$} & A-Less than 2 years & 47 & 2.37 & .83 & \multirow{4}{*}{9.91} & \multirow{4}{*}{.000} & $\mathrm{~B}, \mathrm{C}, \mathrm{D}>\mathrm{A}$ \\
\hline & B-3-5 years & 65 & 3.10 & .81 & & & \\
\hline & C-6-10 years & 39 & 3.06 & .67 & & & \\
\hline & D-11 years and above & 86 & 3.04 & .79 & & & \\
\hline \multirow{4}{*}{ Physical Dedication } & A-Less than 2 years & 47 & 4.32 & .67 & \multirow{4}{*}{2.29} & \multirow{4}{*}{.079} & \\
\hline & B-3-5 years & 65 & 4.14 & .69 & & & \\
\hline & C-6-10 years & 39 & 3.93 & .89 & & & \\
\hline & D-11 years and above & 86 & 4.19 & .60 & & & \\
\hline \multirow{4}{*}{ Emotional Dedication } & A-Less than 2 years & 47 & 4.22 & .76 & \multirow{4}{*}{3.73} & \multirow{4}{*}{.012} & $\mathrm{~A}>\mathrm{C}, \mathrm{D}$ \\
\hline & B-3-5 years & 65 & 3.91 & .92 & & & \\
\hline & C-6-10 years & 39 & 3.59 & .93 & & & \\
\hline & D-11 years and above & 86 & 3.88 & .86 & & & \\
\hline
\end{tabular}




\begin{tabular}{llllllll}
\hline & A-Less than 2 years & 47 & 4.22 & .67 & & & A>B, C, D \\
& B-3-5 years & 65 & 3.89 & .70 & 2.77 & .043 & \\
& Cognitive Dedication years & 39 & 3.81 & .82 & & & \\
& D-11 years and above & 86 & 3.91 & .78 & & & \\
\hline \multirow{3}{*}{ ORGANIZATIONAL } & A-Less than 2 years & 47 & 4.25 & .64 & & & A>B, C, D \\
DEDICATION & B-3-5 years & 65 & 3.98 & .70 & 3.45 & .017 & \\
& C-6-10 years & 39 & 3.78 & .80 & & & \\
& D-11 years and above & 86 & 4.00 & .65 & & & \\
\hline
\end{tabular}

Perceived organizational support $(\mathrm{F}=7.40 ; \mathrm{p}<0.05)$, organizational depression $(\mathrm{F}=9.91 ; \mathrm{p}<0.05)$, emotional dedication $(\mathrm{F}=3.73 ; \mathrm{p}<0.05)$, cognitive dedication $(\mathrm{F}=2.77 ; \mathrm{p}<0.05)$, organizational dedication $(\mathrm{F}=3.45 ; \mathrm{p}<0.05)$ scores were found to differ significantly by total working period. According to results of LSD post hoc test (Table 19);

- Perceived organizational support, cognitive dedication and organizational dedication scores of participants who total working period less than 2 year is significantly higher than the scores of participants who 2 years and above total working period.

- Organizational depression scores of participants who total working period 2 years and above is significantly higher than the scores of participants who less than 2-year total working period.

- Emotional dedication scores of participants who total working period less than 2 year is significantly higher than the scores of participants who 6 years and above total working period.

Physical dedication scores was not found to differ significantly by total working period (Table 19).

Table 20 shows the one-way ANOVA test result of comparing the scale scores according to total number of employees in this organization.

Table 20: Comparison of Scale Scores According to Total Number of Employees in This Organization

\begin{tabular}{|c|c|c|c|c|c|c|c|}
\hline Scale and Dimension & $\begin{array}{l}\text { Total Number of Employees } \\
\text { in This Organization }\end{array}$ & $\mathrm{n}$ & $\overline{\mathrm{X}}$ & SD & $\mathrm{n}$ & $\mathrm{p}$ & $\begin{array}{l}\text { Significant } \\
\text { Difference }\end{array}$ \\
\hline \multirow{3}{*}{$\begin{array}{l}\text { PERCEIVED } \\
\text { ORGANIZATIONAL } \\
\text { SUPPORT }\end{array}$} & A-Less than 1000 people & 82 & 3.01 & .86 & \multirow{3}{*}{3.04} & \multirow{3}{*}{.050} & \\
\hline & B-1000-3000 people & 101 & 2.87 & .93 & & & \\
\hline & C-3001 or more & 54 & 3.24 & .87 & & & \\
\hline \multirow{3}{*}{$\begin{array}{l}\text { ORGANIZATIONAL } \\
\text { DEPRESSION }\end{array}$} & A-Less than 1000 people & 82 & 2.93 & .78 & \multirow{3}{*}{3.10} & \multirow{3}{*}{.047} & $\mathrm{~B}>\mathrm{C}$ \\
\hline & B-1000-3000 people & 101 & 3.05 & .84 & & & \\
\hline & C-3001 or more & 54 & 2.71 & .85 & & & \\
\hline \multirow{3}{*}{ Physical Dedication } & A-Less than 1000 people & 82 & 4.11 & .73 & \multirow{3}{*}{.80} & \multirow{3}{*}{.452} & \\
\hline & B-1000-3000 people & 101 & 4.23 & .73 & & & \\
\hline & C-3001 or more & 54 & 4.10 & .60 & & & \\
\hline
\end{tabular}




\begin{tabular}{|c|c|c|c|c|c|c|}
\hline \multirow{3}{*}{ Emotional Dedication } & A-Less than 1000 people & 82 & 3.75 & .91 & \multirow{3}{*}{2.38} & \multirow{3}{*}{.095} \\
\hline & B-1000-3000 people & 101 & 4.03 & .91 & & \\
\hline & C-3001 or more & 54 & 3.92 & .77 & & \\
\hline \multirow{3}{*}{ Cognitive Dedication } & A-Less than 1000 people & 82 & 3.92 & .76 & \multirow{3}{*}{.38} & \multirow{3}{*}{.682} \\
\hline & B-1000-3000 people & 101 & 3.94 & .78 & & \\
\hline & C-3001 or more & 54 & 4.03 & .70 & & \\
\hline \multirow{3}{*}{$\begin{array}{l}\text { ORGANIZATIONAL } \\
\text { DEDICATION }\end{array}$} & A-Less than 1000 people & 82 & 3.93 & .73 & \multirow{3}{*}{.88} & \multirow{3}{*}{.415} \\
\hline & B-1000-3000 people & 101 & 4.06 & .72 & & \\
\hline & C-3001 or more & 54 & 4.02 & .63 & & \\
\hline
\end{tabular}

Organizational depression $(\mathrm{F}=3.10 ; \mathrm{p}<0.05)$ scores were found to differ significantly by total number of employees in this organization. According to results of LSD post hoc test; organizational depression scores of participants who total number of employees in their organization 1000-3000 people is significantly higher than the scores of participants who their 3001 or more people (Table 20).

According to the results in Table 20, perceived organizational support, physical, emotional, cognitive, organizational dedication scores were not found to differ significantly by total number of employees in this organization.

\section{Conclusion and Discussion}

In this study the impact of perceived organizational support on organizational depression and dedication is examined. This study finds the perception of organizational support has a negative effect on organizational depression; a positive effect on organizational dedication; none of the variables differed by gender, marital status and generations. It is an expected result that people who are supported by their organization get away from depression and increase their organizational dedication.

According to the results of the research, it is seen that as the level of education increases, the expectations of the employees increase, as the seniority level of work in the same enterprise or in a different enterprise increases, the dedication and organizational support perception decreases, but the organization depression increases. It has been determined that the number of employees also affects the organization depression and the organization depression is higher in enterprises with less than 3000 employees. Therefore, it is recommended that the employees always carry out activities aimed at keeping their excitement alive, and the level of education, seniority and number of employees should be taken into account while implementing human resources practices for the organization to work more efficiently and ensure sustainability.

There may be some possible limitations in this study. The first is about citing and attributing previous research studies is the basis of the literature review for the study and provides theoretical foundations 
for the research question you are researching. Depending on the scope of the research topic, previous research studies may be considered as an important opportunity to identify new gaps in the literature and to reveal the need for further development in the field of study. From the methodological aspect, this research is among the first studies that simultaneously look at the relationship between perceived organizational support and organizational depression and dedication. The findings of this study always shed some light to keep the excitement of the employees alive. Managers of organizations could benefit from the recommendations offered. Lack of research parallel to the research topic in the related literature prevents comparison but supports the results of researches with similar concepts. In this context, actions that increase perceived organizational support reduce employee depression and increase employee commitment according to the research result made by Akabas \& Kurzman (2005) and was found as a significant variable on impacting employee commitment (İnce, 2016).

The second limitation concerns that our research is limited to 237 participants and scales applied. When conducting a research, it is important to have a sufficient sample size to achieve a valid research result. The larger the sample, the more precise your results will be. If your sample size is too small, it will be difficult to define meaningful relationships from the data. In this context increasing the number of people participating in the research will support the achievement of more generalizable results, it will be useful in determining moderator or mediator variables if the variables (personality traits, subjective well-being etc.) that may have an impact on perceived organizational support, depression and dedication analyzed together. Taking a study by comparing the participants from different sectors based on the sector variable will also be useful in terms of revealing sectoral differences.

This research was not carried out during the coronavirus period. Coronavirus affected people all over the world and working life. The same sample group can be evaluated after the coronavirus period to analysis the effects of Coronavirus.

\section{Author Contribution}

Authors made literature review together. They also have equal contribution to collection and analyze of data and interpreted the findings, conclusion and discussion part.

\section{Conflict of Interest}

No conflict of interest was reported by the authors.

\section{Financial Support}

The authors has not received any financial support for this study. 


\section{References}

Akabas, S. H., Kurzman, S. H. (2005). Work and the workplace: a resource for innovative policy and practice. New York: Columbia University Press.

Akçakanat, T., Uzunbacak, H.H. \& Köse, S. (2018). Akademisyenlerin psikolojik sağlamlık ve mutluluklarının belirleyicileri olarak sosyal ve örgütsel destek, İşletme Araştırmaları Dergisi, 10(3), 73-193.

Aktürk, A. (2019). Öğretmenlerin damgalama eğilimleri ve örgütsel muhalefet davranışlarının örgütsel depresyonu etkisi. Yüksek Lisans Tezi, Necmettin Erbakan Üniversitesi Eğitim Bilimleri Enstitüsü, Konya.

Aytekin, M. (2016). Lider üye etkileşiminin örgütsel adanmışlı üzerine etkisi. Yüksek Lisans Tezi, Süleyman Demirel Üniversitesi Sosyal Bilimler Enstitüsü, Isparta.

Bakan, I., Taşlıyan, M., Taş, F.\& Aka, N. (2015). Örgüt depresyonu ve iş tatmini arasındaki ilişki; bir üniversitedeki akademisyenler üzerinde alan araştırması. Kahramanmaraş Sütçü İmam Üniversitesi İktisadi ve İdari Bilimler Fakültesi Dergisi, 4(1), 296 - 315.

Beck, A. T. (1975). The Diagnis and Management of Depression. 2nd Edition, Philadelphia: University of Pennysylvania Press.

Bilckik, G. S. (2000). Organizational depression. HVఓ HN: Hospitals and Health Networks, 74(2),34-38.

Blau, P. M. (1964). Exchange and power in social life. New York: John Wiley.

Boylu, Y., Pelit, E.\& Güçer, E. (2007). Akademisyenlerin örgütsel bağlllık düzeyleri üzerine bir araştırma. Finans, Politik \& Ekonomik Yorumlar. 44(11), 55-74.

Büyüköztürk, Ş. (2011). Sosyal bilimler için veri analizi el kitabı (14. Baskı). Ankara: PEGEM Akademi.

Chen Z. X, Eisenberger R, Johnson KM, Sucharski I. L\& Aselage J. (2009). Perceived organizational support and extra-role performance: Which leads to which? Journal of Social Psychology, 149(1), 119-24.

Cheng, L., Cui, Y., Chen, O., Ye, Y., Liu, Y, Zhang, F., Zeng, W.\& Hu, X. (2009). Paediatric nurses' general selfefficacy perceived organizational support and perceived professional benefits from class a tertiary hospital in Jilin province of China: The mediating effect of nursing practice environment. BMC Health Services Research, 20(12), 1-9.

Cohen, W., Cohen, N. (1993). Paranoid corporation: Advice from on organizational shrink. New York American Management Assocation: Emerald.

Çalışkan, S. C. (2014). Pozitif örgütsel davranış değişkenleri ile yeni araştırma modelleri geliştirme arayışları: Pozitif örgütsel davranış değişkenlerinin işe adanmışlık, tükenmişlik ve sinizm üzerine etkileri ve bu etkileşimde örgütsel adalet algısının aracılık rolü üzerine bir araştırma. Dokuz Eylül Üniversitesi Sosyal Bilimler Enstitüsü Dergisi, 16(3), 363-382.

Çeler, A. (2015). Tip fakültesindeki araştırma görevlilerinde depresyon düzeyinin iş doyumu ile ilişkisinin incelenmesi. Konuralp Tip Dergisi, 7(3), 125-133.

Çokluk, Ö., Şekercioğlu, G.\& Büyüköztürk, Ş. (2010). Sosyal bilimler için çok değişkenli istatistik: SPSS ve Lisrel uygulamaları. Ankara: PEGEM Akademi.

Demircan, C. N., Yıldız, S. (2009). Örgütsel adaletin iş tatmini üzerindeki etkisi. Elektronik Sosyal Bilimler Dergisi, 8 (28), 68-90.

Diken, A., Koçyiğit, N., Topaloğlu, E.Ö. \& Yılmaz, A. (2019). İşgörenlerde algılanan örgütsel destek algısı ile örgütsel bağllılı ilişkisinde iş tatmininin aracı rolü. İsletme Araştırmaları Dergisi, 11(4), 2698-2716.

Dökmen, Ü. (2004). Küçük şeyler. İstanbul: Sistem Yayıncllık.

Düşükcan, M., Demirel, E.T. \& Sezgin, E.E. (2019). Örgütsel destek üzerinden psikolojik sözleşmeyi güçlendirmek. Konya: Eğitim Yayınevi. 
Eisenberger, R., Stinglhamber, F. (2011). Perceived organizational support: Fostering enthusiastic and productive employees. Washington, DC.: APA Books.

Firal, A. Farok, A., Rohaida, S.\& Zainal, M. (2017). Talent management at service sector: linking organizational based self-esteem to servant leadership, interactional justice and job dedication. Asian Journal of Scientific Research, 10(4), 363-371.

Bell DeTienne, K., Hooley, J. M., Larrocha, C. \& Reay, A. (2020). How to manage an employee with depression. Harvard Business Review, https://store.hbr.org/product/how-to-manage-an-employee-withdepression/h05d03?sku=H05D03-PDF-ENG.

Gerrig, R. J., Zimbardo, P. G. (2015). Psikolojiye giriş: Psikoloji ve yaşam. 19. Basımdan Çeviri, Çeviren: Gamze Sart, Ankara: Nobel Akademik Yayıncılık.

Gill, A. S., Mathur, N. (2007). Improving employee dedication and pro-social behavior. International Journal of Contemporary Hospitality Management, 19(4), 328-334.

Gillet, N., Fouquereau E., Huyghebaert T. \& Colombat P. (2016). Effects of perceived organizational support and job characteristics on job anxiety and burnout: The mediating role of psychological need satisfaction. Psychologie Francaise, 61(2), 73-81.

Gray, H. (2008). Work and depression in economic organizations: The need for action. Emerald Group Publishing, 22(3), 9-11.

Güleç, C. (2009). Psikiyatrinin ABC'si. İstanbul: Say Yayınları.

Huchzermeier, A., Mercikoğlu, C. \& Scholz, T. R. (2019). Liderler İçin Çalışan Bağgllı̆̆ı Rehberi. Harvard Business Review Türkiye, 8(7), 102-107.

İnce, A. R. (2016). Algılanan örgütsel desteğin işe adanmışlık üzerindeki etkisinde yönetici desteğinin aracilık rolü. Electronic Journal of Social Sciences, 15(57), 649-660.

Kahn, W. A. (1990). Psychological conditions of personal engagement and disengagement at work. Academy of Management Journal, 33(4), 692-724.

Keleş, E. (2016). öğretmen görüşlerine göre liselerde örgütsel depresyon. Yüksek Lisans Tezi, Yüzüncü Yıl Üniversitesi Eğitim Bilimleri Enstitüsü, Eğitim Bilimleri Anabilim Dalı, Eğitim Yönetimi Teftişi Planlaması ve Ekonomisi Bilim Dalı, Van.

Köroğlu, E. (2014). Kişilik bozuklukları. Ankara: HBY Basım Yayın.

Kurtpınar, M. (2011). Birey-örgüt uyumunun bireysel performans üzerindeki etkisinde kişilik özellikleri ve işe adanmışlğın rolü. Harp Akademileri Komutanlığı, Stratejik Araştırmalar Enstitüsü Müdürlüğü. Yayımlanmamış Yüksek Lisans Tezi, İstanbul.

Laschinger, H. K. S., Wilk, P., Cho, J., \& Greco, P. (2009). Empowerment, engagement and perceived effectiveness in nursing work environments: Does experience matter? Journal of Nursing Management, 17(5), 636646.

Manfred, F. R., De Vries, K. (2001). Organizational Paradoxes: Clinical approaches to management. Oxon: Routledge.

McGraw-Hill, (2016). Aklımın aklı: Psikoloji. 2. Basımdan Çeviri, Çevirenler: Mithat Durak, Emre Şenol Durak, Ufuk Kocatepe, Ankara: Nobel Akademik Yayincilık.

Muldoon, J., Keough, S. M. \& Liguori, E. W. (2017). The role of job dedication in organizational citizenship behavior performance. Management Research Review, 40(10), 1042-1057.

Oblinger, D. G., Oblinger, J. L. (2005). Educating the net generation. North Carolina: Educause Transforming Education.

Olshan, N. H. (1982). Depression. New York. 
Özdevecioğlu, M. (2003). Algılanan örgütsel destek ile örgütsel bağllılk arasındaki ilişkilerin belirlenmesine yönelik bir araştırma. D.E.Ü.İ.I.B.F. Dergisi, 18(2), 113 - 130.

Öztürk, M. \& Eryeşil, K. (2016). Lider-üye etkileşimi ve örgütsel destek algıllarının çalışanların işten ayrılma niyeti üzerindeki etkisi. Selçuk Üniversitesi Sosyal Bilimler Meslek Yüksekokulu Dergisi. 19(2), 123-141.

Probst, T.M., Petitta, L., Barbaranelli, C., Austin, C. (2018), Safety-Related moral disengagement in response to job insecurity: Counterintuitive effects of perceived organizational and supervisor support. Journal of Business Ethics, 162, 343-358.

Sezer, S. (2010). Bilişsel davranışçı yaklaşımla bütünleştirilen hobi terapi uygulamasının bir eğitim kurumunun örgüt depresyonu üzerindeki etkisi. Balıkesir Üniversitesi Sosyal bilimler Enstitüsü Dergisi, 13(23), 36-50.

Sezer, S. (2011). Örgüt depresyonu ölçeğinin geliştirilmesi ve psikometrik niteliklerinin belirlenmesi. I̧s-Güç Endüstri İlişkileri ve İnsan Kaynakları Dergisi. 13(1), 39-50.

Smith, E. E., Nolen-Hoeksema, S., Fredrickson, B. \& Loftus, G. R. (2016). Psikolojiye giriş. 4. Baskı,14. Edisyon, Çevirenler: Öznur Öncül, Deniz Fettahoğlu, Arkadaş Yayınevi: Ankara.

Stinglhamber, F., Ohana, M., Caesens, G. \& Meyer, M. (2020). Perceived organizational support: the interactive role of coworkers' perceptions and employees'voice. Employee Relations: The International Journal, 42(1), 107-124.

Sonnentag, S. (2003). Recovery, work engagement, and proactive behavior: a new look at the interface between nonwork and work. Journal of Applied Psychology, 88(3), 518-528.

Taştan, S.B. (2014). Örgüt iklimi ile örgütsel adanmışlık arasındaki ilişkide psikolojik güçlendirme algısının ara değiş̧en olarak incelenmesi ve psikososyal kaynakların rolü: kamu kesimi çalışanları üzerine bir araştırma. Organizasyon ve Yönetim Bilimleri Dergisi, 6(1), 91-106.

Toytok, E. H. (2018). Okul yöneticilerinin kullandıkları güç türleri ve örgütsel depresyon: Bir ilişkisel tarama modeli. EKEV Akademi Dergisi, 22(76), 109-126.

Turhan, Ö. (2019). Beş faktör kişilik özelliklerinin iş tatmini üzerindeki etkisinde depresyonun aracılık rolü. IBAD Sosyal Bilimler Dergisi, 5, 9-21.

Uçar, L. (2016). Okul yöneticilerinin kullandıkları güç türleri ve örgütsel depresyon: bir ilişkisel tarama modeli. Yüksek Lisans Tezi, Siirt Üniversitesi Sosyal Bilimler Enstitüsü, Siirt.

Uğurlu, Z., Kral, E. \& Aksoy, I. G. (2011). İlköğretim okul yöneticilerinin görüşlerine göre öğretmenlerin sosyalleşmesinde kullandıkları örgütsel sosyalleşme strateji ve taktikleri. In 2nd International Conference on New Trends in Education and Their Implications, January 2013.

Yavan, Ö. (2016). Örgütsel davranış düzleminde adanmışlı. Pamukkale Üniversitesi Sosyal Bilimler Enstitüsü Dergisi, 25, 278-296.

Yüksel, H. (2005). İşletmenin tatmin üzerindeki etkileri: Bir işletmede yapılan görgül bir çalışma. Doğuş Üniversitesi Dergisi, 6(2), 291-306.

\section{Resume}

Gülbeniz AKDUMAN is part time lecturer of Institute of Graduate Programs, Human Resources Management Programme, Bilgi University. She holds a Ph.D. in Business Administration from İstanbul Arel University. Her research interests focus on the areas of management and organization, organizational behaviour, human resources management and happiness management. 
Zeynep HATİPOĞLU, is associate professor of Faculty of Economics and Administrative Sciences, Department of Business Administration, İstanbul Arel University. She holds an associate professor in Business Administration from İstanbul Arel University. Her research interests focus on the areas of management and organization, organizational behaviour and human resources management. 